\title{
Front Matter: Volume 11485
}

, "Front Matter: Volume 11485," Proc. SPIE 11485, Reflection, Scattering, and Diffraction from Surfaces VII, 1148501 (15 September 2020); doi: $10.1117 / 12.2581570$

SPIE. Event: SPIE Optical Engineering + Applications, 2020, Online Only 


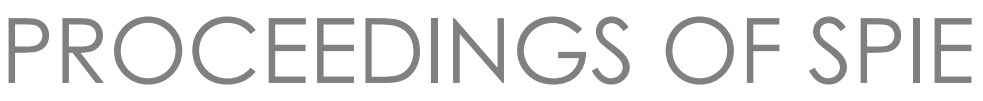

\section{Reflection, Scattering, and Diffraction from Surfaces VII}

Leonard M. Hanssen

Editor

24 August - 4 September 2020

Online Only, United States

Sponsored and Published by

SPIE 
The papers in this volume were part of the technical conference cited on the cover and title page. Papers were selected and subject to review by the editors and conference program committee. Some conference presentations may not be available for publication. Additional papers and presentation recordings may be available online in the SPIE Digital Library at SPIEDigitalLibrary.org.

The papers reflect the work and thoughts of the authors and are published herein as submitted. The publisher is not responsible for the validity of the information or for any outcomes resulting from reliance thereon.

Please use the following format to cite material from these proceedings:

Author(s), "Title of Paper," in Reflection, Scattering, and Diffraction from Surfaces VII, edited by Leonard M. Hanssen, Proceedings of SPIE Vol. 11485 (SPIE, Bellingham, WA, 2020) Seven-digit Article CID Number.

ISSN: 0277-786X

ISSN: 1996-756X (electronic)

ISBN: 9781510637764

ISBN: 9781510637771 (electronic)

Published by

SPIE

P.O. Box 10, Bellingham, Washington 98227-0010 USA

Telephone +1 3606763290 (Pacific Time) · Fax +1 3606471445

SPIE.org

Copyright (c) 2020, Society of Photo-Optical Instrumentation Engineers.

Copying of material in this book for internal or personal use, or for the internal or personal use of specific clients, beyond the fair use provisions granted by the U.S. Copyright Law is authorized by SPIE subject to payment of copying fees. The Transactional Reporting Service base fee for this volume is $\$ 21.00$ per article (or portion thereof), which should be paid directly to the Copyright Clearance Center (CCC), 222 Rosewood Drive, Danvers, MA 01923. Payment may also be made electronically through CCC Online at copyright.com. Other copying for republication, resale, advertising or promotion, or any form of systematic or multiple reproduction of any material in this book is prohibited except with permission in writing from the publisher. The CCC fee code is $0277-$ $786 \mathrm{X} / 20 / \$ 21.00$.

Printed in the United States of America by Curran Associates, Inc., under license from SPIE.

Publication of record for individual papers is online in the SPIE Digital Library.

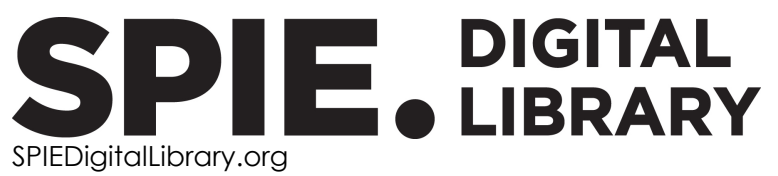

Paper Numbering: Proceedings of SPIE follow an e-First publication model. A unique citation identifier (CID) number is assigned to each article at the time of publication. Utilization of CIDs allows articles to be fully citable as soon as they are published online, and connects the same identifier to all online and print versions of the publication. SPIE uses a seven-digit CID article numbering system structured as follows:

- The first five digits correspond to the SPIE volume number.

- The last two digits indicate publication order within the volume using a Base 36 numbering system employing both numerals and letters. These two-number sets start with $00,01,02,03,04$, 05, 06, 07, 08, 09, OA, OB ... 0Z, followed by 10-1Z, 20-2Z, etc. The CID Number appears on each page of the manuscript. 


\section{Contents}

THEORY AND MODELING I

1148508 Induced polarization response within a spheroidal particle from an incident electromagnetic wave [1 1485-6]

INSTRUMENTATION AND APPLICATIONS I

11485 OA BSDF measurements and analyses of specular samples using a table-top goniometer in support of remote sensing instruments [11485-8]

$11485 \mathrm{OB} \quad$ Augmenting CASI ${ }^{\circledR}$ BRDF measurement device to measure out-of-plane scatter with CCD pixel array [11485-9]

MEASUREMENT METHODOLOGY

11485 OD Direct method of extracting complex refractive index from routine Fourier transform infrared reflectance/transmittance measurements (Invited Paper) [1 1485-1 1]

11485 OE Modal imaging of a laser Gaussian-beam reflected off a surface [1 1485-12]

THEORY AND MODELING ॥

11485 0J PySCATMECH: a Python interface to the SCATMECH library of scattering codes [11485-17]

INSTRUMENTATION AND APPLICATIONS II

11485 OK High temperature reflectometer for spatially resolved spectral directional emissivity of laser powder bed fusion processes [11485-18]

\section{POSTER SESSION}

11485 ON Signal-to-noise ratio evaluation for the nanometer-scale patterned defect inspection using dark-field microscopy with tailored polarization illumination [11485-21] 
1148500 High-dynamic-range instrument for characterisation of the angle-dependent reflectivity of ITER plasma-facing components [11485-22]

11485 OP Performance enhancement of WDM-PONs: Interferometric noise reduction [1 1485-23] 